\title{
Glutathione S-transferase mu 1 (GSTM1) and theta 1 (GSTT1) genetic polymorphisms and atopic asthma in children from Southeastern Brazil
}

\author{
Carmen Silvia Passos Lima ${ }^{1}$, Iramaia Angélica Néri ${ }^{1}$, Gustavo Jacob Lourenço ${ }^{1}$, \\ Isabel Cristina Jacinto Faria ${ }^{2}$, José Dirceu Ribeiro ${ }^{3}$ and Carmen Silvia Bertuzzo ${ }^{2}$ \\ ${ }^{1}$ Departamento de Clínica Médica, Faculdade de Ciências Médicas, Universidade Estadual de Campinas, \\ Campinas, SP, Brazil. \\ ${ }^{2}$ Departament de Genética, Faculdade de Ciências Médicas, Universidade Estadual de Campinas, \\ Campinas, SP, Brazil. \\ ${ }^{3}$ Departamento de Pediatria, Faculdade de Ciências Médicas, Universidade Estadual de Campinas, \\ Campinas, SP, Brazil.
}

\begin{abstract}
Xenobiotics can trigger degranulation of eosinophils and mast cells. In this process, the cells release several substances leading to bronchial hyperactivity, the main feature of atopic asthma (AA). GSTM1 and GSTT1 genes encode enzymes involved in the inactivation of these compounds. Both genes are polymorphic in humans and have a null variant genotype in which both the gene and corresponding enzyme are absent. An increased risk for disease in individuals with the null GST genotypes is therefore, but this issue is controversial. The aim of this study was to investigate the influence of the GSTM1 and GSTT1 genotypes on the occurrence of AA, as well as on its clinical manifestations. Genomic DNA from 86 patients and 258 controls was analyzed by polymerase chain reaction. The frequency of the GSTM1 null genotype in patients was higher than that found in controls $(60.5 \%$ versus $40.3 \%, p=0.002)$. In individuals with the GSTM1 null genotype the risk of manifested AA was 2.3-fold higher $(95 \% \mathrm{Cl}$ : 1.4-3.7) than for others. In contrast, similar frequencies of GSTT1 null and combined GSTM1 plus GSTT1 null genotypes were seen in both groups. No differences in genotype frequencies were perceived in patients stratified by age, gender, ethnic origin, and severity of the disease. These results suggest that the inherited absence of the GSTM1 metabolic pathway may alter the risk of AA in southeastern Brazilian children, although this must be confirmed by further studies with a larger cohort of patients and age-matched controls from the distinct regions of the country.
\end{abstract}

Key words: Atopic asthma, pathogenesis, GSTM1 gene, GSTT1 gene.

Received: January 20, 2010; Accepted: February 5, 2010.

Atopic asthma (AA), a disease caused by a combination of genetic and environmental factors, is characterized by a broad variety of clinical manifestations these ranging from increased bronchial susceptibility in healthy individuals to a lethal form.

Previous studies have shown that a great variety of xenobiotics can trigger degranulation of eosinophils and mast cells, with the subsequent release of various substances, active in bronchial inflammation and spasms, the main events in pathogenesis of the disease (Demoly et al., 1997). Enzymes of the glutathione S-transferase (GST) system protect the bronchii from the effects of these agents by transforming them into less active compounds (Demoly

Send correspondence to Carmen S.P. Lima. Departamento de Clínica Médica, Faculdade de Ciências Médicas, Universidade Estadual de Campinas, Rua Alexander Fleming 181, Cidade Universitária "Zeferino Vaz", Distrito de Barão Geraldo, 13083-970 Campinas, SP, Brazil. E-mail: carmenl@fcm.unicamp.br. et al., 1997; Scoggan et al., 1997; Hayes et al., 2005). GSTM1 and GSTT1 genes of the GST system are polymorphic and homozygous null in about $40 \%-60 \%$ and $10 \%-20 \%$ of individuals of distinct ethnic origin (Hayes and Pulford, 1995; Gattás et al., 2004; Hayes et al., 2005), resulting in a lack of the active proteins. Apparently, people with a reduced ability in detoxification or catabolism of inductors of bronchial inflammation are under an increased risk for AA (Ketley et al., 1975; Scoggan et al., 1997). However, the association of GST null genotypes with this risk is controversial (Ivaschenko et al., 2001; Freidin et al., 2002; Brasch-Andersen et al., 2004; Saadat et al., 2004; Tamer et al., 2004; Ercan et al., 2006; Holla et al., 2006; Hanene et al., 2007; Mak et al., 2007; Salam et al., 2007; Imboden et al., 2008; Islam et al., 2009; Castro-Giner et al., 2009; Rogers et al., 2009).

The high prevalence of AA (Chatkin et al., 2003) and environmentally-related diseases (Ruiz et al., 1994) in 
southeastern Brazil has already been described. Thus, the identification of GST genotypes in AA patients and controls from this part of the country was considered essential for testing their influence in the risk and on clinical manifestations of the disease in the population as a whole.

We analyzed 86 consecutive AA patients (median age 10 years and range 7-17; 39 males and 47 females; 79 Caucasians and 7 Afro-Americans) seen at the University Hospital of the State University of Campinas, from July, 2005 to January, 2006. A background history of recurrent and reversible symptoms of air passage obstruction, high serum IgE levels, positive test results to at least one of the recognised allergens inoculated in skin, and a family history of allergy were required for AA diagnosis, in accordance with current Global Initiative for Asthma (GINA) criteria (GINA Report, Global Strategy for Asthma Management and Prevention, 2009). None of the patients enrolled in this study had any identifiable alcohol use or smoking history. All the patients were students and were classified as having a mild, moderate or severe form of AA, as previously described by Warner et al. (1998). The control group consisted of 258 healthy blood donors (median age 53 years and range 25-62; 117 males and 141 females; 237 Caucasians and 21 Afro-Americans) from the same University Hospital, who were matched against the controls by gender and ethnic origin, thereby providing a representative group of the general population that seeks medical assistance in this region. Both patients and controls were classified as Caucasians or Afro-Americans based on individual phenotype. The study was approved by the local review board guidelines, and all subjects gave written and informed consent in accordance with the Helsinki Declaration.

Genomic DNA was obtained from the peripheral blood of all subjects. GSTM1 and GSTT1 genes were amplified by multiplex polymerase chain reaction (PCR) in the same reaction, including the amplification of a $\beta$-globin gene fragment used as a control of the DNA sample (Arruda et al., 2001). Genotypes were analyzed by electrophoresis on a $2.0 \%$ agarose gel, and only those PCR signals were considered in which the corresponding $\beta$-globin gene internal control was evident.

Statistical significance of the differences between groups was calculated by the chi-square or Fisher exact tests. Crude odds ratios (ORs) were calculated and are given with 95\% confidence intervals (CI). Logistic regression analysis was used to obtain gender and ethnic origin-adjusted ORs. Factors with $\mathrm{p}<0.05$ were considered statistically significant. All analyses were undertaken using the statistical package SAS System for Windows, version 8.1 (SAS Institute Incorporation, USA).

A high prevalence of the GSTM1 null genotype was seen in our AA patients. Individuals with the GSTM1 null genotype had a 2.3 -fold increased risk for manifested disease than others. No differences in frequencies of the GSTT1 null and GSTM1 plus GSTT1 null genotypes were found in patients and controls. Individuals with distinct genotypes incurred the same AA (Table 1). Similar frequencies of the GSTM1 null, GSTT1 null and GSTM1 plus GSTT1 null genotypes were seen in patients stratified by age at diagnosis, gender, race, and severity of the disease (Table 2).

Upon investigating the GSTM1 and GSTT1 genotype frequencies of the GST system in Brazilian individuals, we found that the GSTM1 null genotype was associated with an increased risk for AA. There are several explanations for the role of GSTs in disease pathogenesis, the first being that xenobiotics are not discharged from the organism in the absence of these enzymes, and therefore may trigger mast cell degranulation (Demoly et al., 1997; Hayes et al., 2005). Secondly, it is known that leukotrienes released by mast cells and eosinophils, important compounds in bronchial constriction, are inactivated by GSTs (Scoggan et al., 1997). Thus, persistent bronchial spasms may be expected in the absence of enzymes encoded by the GSTM1 and GSTT1 genes. A further explanation is that GSTs are capable of binding steroid hormones, which are inhibitors of eosinophils involved in a late stage of the allergic reaction, and to transport them to tissues (Ketley et al., 1975). The absence of these enzymes may, therefore, contribute to asthma by abnormalities in the transport of inflammatory inhibitors to bronchioles. Taken together, these observations suggest that GSTs act at different stages in the formation of an asthmatic reaction.

The results of 14 epidemiological studies on the role of GST genotypes in asthma, undertaken in countries of the northern hemisphere, were controversial. The GSTM1 null genotype was associated with an increased risk for disease

Table 1 - GSTM1 and GSTT1 genotypes in atopic asthma patients and controls.

\begin{tabular}{|c|c|c|c|c|c|c|c|}
\hline & \multicolumn{2}{|c|}{ GSTM1 } & \multicolumn{2}{|c|}{ GSTT1 } & \multicolumn{3}{|c|}{ GSTM1/T1 } \\
\hline & Present n $(\%)$ & Null n (\%) & Present n $(\%)$ & Null n (\%) & Both present $\mathrm{n}(\%)$ & One null n (\%) & Both null n (\%) \\
\hline Patients & $34(39.5)$ & $52(60.5)$ & $72(83.7)$ & $14(16.3)$ & $27(31.4)$ & $52(60.5)$ & $7(8.1)$ \\
\hline Controls & $154(59.7)$ & $104(40.3)$ & $213(82.6)$ & $45(17.4)$ & $130(50.4)$ & $107(41.5)$ & $21(8.1)$ \\
\hline OR (CI 95\%) & 1.0 (ref) & $2.3(1.3-3.3)$ & 1.0 (ref) & $0.9(0.5-1.7)$ & 1.0 (ref) & $2.3(1.4-4.0)$ & $1.6(0.6-4.1)$ \\
\hline $\mathrm{p}$ value & 0.002 & & 0.870 & & & 0.002 & 0.425 \\
\hline
\end{tabular}

OR: odds ratio; CI: confidence interval. 
Table 2 - GSTM1 and $T 1$ genotypes in atopic asthma patients stratified by pertinent characteristics.

\begin{tabular}{|c|c|c|c|c|c|c|c|c|}
\hline \multirow[t]{2}{*}{ Clinical features } & \multirow[t]{2}{*}{$\mathrm{n}$} & \multicolumn{2}{|c|}{ GSTM1 } & \multicolumn{2}{|c|}{ GSTT1 } & \multicolumn{3}{|c|}{ GSTM1/T1 } \\
\hline & & $\begin{array}{c}\text { Present } \\
\mathrm{n}(\%)\end{array}$ & $\begin{array}{l}\text { Null } \\
\text { n (\%) }\end{array}$ & $\begin{array}{c}\text { Present } \\
\mathrm{n}(\%)\end{array}$ & $\begin{array}{l}\text { Null } \\
\text { n (\%) }\end{array}$ & $\begin{array}{c}\text { Both present } \\
\text { n (\%) }\end{array}$ & $\begin{array}{c}\text { One null } \\
\mathrm{n}(\%)\end{array}$ & $\begin{array}{c}\text { Both null } \\
\text { n (\%) }\end{array}$ \\
\hline Median age at diagnosis & 86 & & & & & & & \\
\hline$\leq 10$ years & 51 & $23(26.8)$ & $28(32.5)$ & $42(48.8)$ & $9(10.5)$ & $19(22.1)$ & $27(31.4)$ & $5(5.8)$ \\
\hline$>10$ years & 35 & $11(12.8)$ & $24(27.9)$ & $30(34.9)$ & $5(5.8)$ & $8(9.3)$ & $25(29.1)$ & $2(2.3)$ \\
\hline $\mathrm{p}$ value & & 0.30 & & & 0.90 & reference & 0.18 & 0.96 \\
\hline Gender & 86 & & & & & & & \\
\hline Male & 39 & $16(18.7)$ & $23(26.7)$ & $35(40.7)$ & $4(4.7)$ & $13(15.2)$ & $25(29.0)$ & $1(1.2)$ \\
\hline Female & 47 & $18(20.9)$ & $29(33.7)$ & $37(43.0)$ & $10(11.6)$ & $14(16.2)$ & $27(31.4)$ & $6(7.0)$ \\
\hline $\mathrm{p}$ value & & 0.97 & & 0.28 & & reference & 0.99 & 0.23 \\
\hline Ethnic origin & 86 & & & & & & & \\
\hline Caucasian & 79 & $30(34.9)$ & $49(56.9)$ & $66(76.7)$ & $13(15.1)$ & $23(26.8)$ & $50(58.0)$ & $6(7.0)$ \\
\hline Afro-American & 7 & $4(4.7)$ & $3(3.5)$ & $6(7.0)$ & $1(1.2)$ & $4(4.7)$ & $2(2.3)$ & $1(1.2)$ \\
\hline $\mathrm{p}$ value & & 0.55 & & & 0.88 & reference & 0.19 & 0.97 \\
\hline Severity of disease & 86 & & & & & & & \\
\hline Mild & 28 & $13(15.2)$ & $15(17.4)$ & $22(25.6)$ & $6(7.0)$ & $9(10.5)$ & $17(19.7)$ & $2(2.3)$ \\
\hline Moderate & 21 & $6(7.0)$ & $15(17.4)$ & $19(22.1)$ & $2(2.3)$ & $6(7.0)$ & $13(15.2)$ & $2(2.3)$ \\
\hline Severe & 37 & $15(17.4)$ & $22(25.6)$ & $31(36.0)$ & $6(7.0)$ & $12(13.9)$ & $22(25.6)$ & $3(3.5)$ \\
\hline $\mathrm{p}$ value & & 0.44 & & 0.53 & & reference & 0.96 & 0.93 \\
\hline
\end{tabular}

in some reports (Ivaschenko et al., 2001; Brasch-Andersen et al., 2004; Saadat et al., 2004; Tamer et al., 2004; Hanene et al., 2007; Islam et al., 2009; Rogers et al., 2009), but not in others (Freidin et al., 2002; Ercan et al., 2006; Holla et al., 2006; Mak et al., 2007; Salam et al., 2007; Imboden et al., 2008; Castro-Giner et al., 2009). Similarly, an increased risk was seen in individuals with the GSTT1 null genotype in some studies (Ivaschenko et al., 2001; Brasch-Andersen et al., 2004; Saadat et al., 2004; Tamer et al., 2004; Hanene et al., 2007), whereas no association of the disease with this genotype was noted by others (Freidin et al., 2002; Ercan et al., 2006; Holla et al., 2006; Mak et al., 2007; Salam et al., 2007; Imboden et al., 2008; Islam et al., 2009; Castro-Giner et al., 2009; Rogers et al., 2009). Differences in gene frequencies among various ethnic groups, as well as exposure to environmental chemical agents in the various countries, may explain the differences encountered. The ethnic origin of the Brazilian population is highly heterogeneous (Gattás et al., 2004), consisting of indigenous Amerindians and immigrants from Europe, Africa and Asia whilst populations in the northern hemisphere are usually characterised by ethnical homogeneity. In fact, the frequencies of GSTM1 and GSTT1 null genotypes in controls varied from $40.8 \%$ (Turkey) to $73.5 \%$ (Russia) and $22.1 \%$ (Czech Republic) to 53.3\% (China), respectively, among individuals of distinct populations in consistent studies (Hayes et al., 2005). On the other hand, Brazilian workers are frequently exposed to numerous chemical agents, such as, hexachlorobenzene, carbon tetrachloride, perchloroethylene, solvents, benzopyrene, alachlor, atrazine, lindane and methyl parathion, some of which are known to be metabolised by the enzymes of the GST system (Hayes et al., 2005), besides being involved in bronchial reactivity (Demoly et al., 1997). Unfortunately there was a lack of reliable data focusing individual chemical exposure on the part of our patients and controls, as well as those enrolled in other studies. All the enrolled AA patients were childrens, and therefore apparently had no history of excessive exposure to chemical agents. However, we can not exclude chemical and tobacco exposition in our controls, who were older than our patients.

We also analyzed GST genotypes in clinical features of AA patients, and found no role for GSTM1 and GST1 by age at diagnosis, gender, ethnic origin and severity of the disease. Freidin et al. (2002) and Ercan et al. (2006) also found no association of GST genotypes with severity of the disease. On the contrary, Carrol et al. (2005) and Holla et al. (2006) found an excess of GSTM1 null genotype in patients with malfunction of the lung, thereby implying that a lack of the M1 enzyme could contribute to lung damage in patients with the disease.

In summary, our results are suggestive that the inherited absence of the GSTM1 metabolic pathway may alter the risk for manifested AA in our region, even though no influence on the severity of the disease was detected. However, these results must be confirmed by further studies with a larger cohort of patients and age-matched controls from distinct regions of the country. 


\section{References}

Arruda VR, Lima CSP, Grignoli CRE, Melo MB, Lorand-Metze I, Alberto FL, Saad STO and Costa FF (2001) Increased risk for acute myeloid leukaemia in individuals with glutathione S-transferase mu 1 (GSTM1) and tetha 1 (GSTT1) gene defects. Eur J Haematol 66:383-388.

Brasch-Andersen C, Christiansen L, Tan Q, Haagerup A, Vestbo J and Kruse TA (2004) Possible gene dosage effect of glutathione-S-transferases on atopic asthma: Using real-time PCR for quantification of GSTM1 and GSTT1 gene copy numbers. Hum Mutat 24:208-214.

Carroll WD, Lenney W, Jones PW, Strange RC, Child F, Whyte MK, Primhak RA and Fryer AA (2005) Effects of glutathione S-Transferase M1, T1, and P1 on lung function in asthmatic families. Clin Exp Allergy 35:1155-1161.

Castro-Giner F, Künzli N, Jacquemin B, Forsberg B, de Cid R, Sunyer J, Jarvis D, Briggs D, Vienneau D, Norback D et al. (2009) Environ Health Perspect 117:1919-1924.

Chatkin MN, Menezes AMB, Victora CG and Barros FC (2003) High prevalence of asthma in preschool children in southern Brazil: A population-based study. Pediatr Pulmonol 35:296-301.

Demoly P, Mathieu M, Curiel DT, Godard P, Bousquet J and Michel FB (1997) Gene therapy strategies for asthma. Gene Ther 4:507-516.

Ercan H, Birben E, Dizdar EA, Keskin O, Karaaslan C, Soyer OU, Dut R, Sackesen C, Besler T and Kalayci O (2006) Oxidative stress and genetic and epidemiologic determinants of oxidants injury in childhood asthma. J Allergy Clin Immunol 118:1097-1104.

Freidin MB, Bragina EY, Ogorodova LM and Puzyrev VP (2002) Polymorphism of the theta1 and mul glutathione S-transferase genes (GSTT1, GSTM1) in patients with atopic bronchial asthma from the west Siberian region. Mol Biol (Mosk) 36:630-634.

Gattás GJ, Kato M, Soares-Vieira JA, Siraque MS, Kohler P, Gomes L, Rego MA and Bydlowski SP (2004) Ethnicity and glutathione S-transferase (GSTM1/GSTT1) polymorphisms in a Brazilian population. Braz J Med Biol Res 37:451-458.

Hanene C, Jihene L, Jamel A, Kamel H and Agnes H (2007) Association of GST genes polymorphisms with asthma in Tunisian children. Mediators Inflamm 2007:1-6.

Hayes JD and Pulford DJ (1995) The glutathione S-transferase supergene family: Regulation of GST and the contribution of the isoenzymes to cancer chemoprotection and drug resistence. Crit Rev Biochem Mol Biol 30:445-600.

Hayes JD, Flanagan JU and Jowsey IR (2005) Glutathione transferases. Annu Rev Pharmacol Toxicol 45:51-88.

Holla LI, Stejskalova A and Vasku A (2006) Polymorphisms of the GSTM1 and GSTT1 genes in patients with allergic diseases in Czech population. Allergy 61:265-267.

Imboden M, Rochat T, Brutsche MH, Schindler C, Downs SH, Gerbase MW, Berger W, Probst-Hensch NM and Sapaldia Team T (2008) Glutathione S-transferase genotype increa- ses risk of progression from bronchial hyperresponsiveness to asthma in adults. Thorax 63:322-328.

Islam T, Berhane K, McConnell R, Gauderman WJ, Avol E, Peters JM and Gilliland FD (2009) Glutathione-S-transferase (GST) P1, GSTM1, exercise, ozone and asthma incidence in school children. Thorax 64:197-202.

Ivaschenko TE, Sideleva OG, Petrova MA and Boranov VS (2001) Genetic determinants of predisposition to bronchial asthma. Russ J Genet 37:107-111.

Ketley JN, Habig WH and Jakoby WB (1975) Binding of nonsubstrate ligands to the glutathione S-transferases. J Biol Chem 250:8670-8673.

Mak JC, Ho SP, Leung HC, Cheung AH, Law BK, So LK, Chan CH, Lam WK, Ip MS and Chan-Yeung M (2007) Relationship between glutathione S-transferase gene polymorphisms and enzyme activity in Hong Kong Chinese asthmatics. Clin Exp Allergy 37:1150-1157.

Rogers AJ, Brasch-Andersen C, Ionita-Laza I, Murphy A, Sharma S, Klanderman BJ and Raby BA (2009) The interaction of glutathione S-transferase M1-null variants with tobacco smoke exposure and the development of childhood asthma. Clin Exp Allergy 39:1721-1729.

Ruiz MA, Augusto LGS, Vassallo J, Vigorito AC, Lorand-Metze I and Souza CA (1994) Bone marrow morphology in patients with neutropenia due to chronic exposure to organic solvents. Pathol Res Pract 190:151-154.

Saadat M, Saadat I, Saboori Z and Emad A (2004) Combination of CC16, and GSTT1 genetic polymorphism is associated with asthma. J Allergy Clin Immunol 113:996-998.

Salam MT, Lin PC, Avol EL, Gauderman WJ and Gilliland FD (2007) Microsomal epoxide hydrolasem glutathione Stransferase $\mathrm{P} 1$, traffic and childhood asthma. Thorax 62:1050-1057.

Scoggan KA, Jacobson PJ and Ford-Hutchinson AW (1997) Production of leukotriene $\mathrm{C} 4$ in different human tissues is attributable to distinct membrane bound biosynthetic enzymes. $\mathrm{J}$ Biol Chem 272:10182-10187.

Tamer L, Calikoglu M, Ates NA, Yildirim H, Ercan B, Saritas E, Unlu A and Atik U (2004) Glutathione-S-transferase gene polymorphisms (GSTT1, GSTM1, GSTP1) as increased risk factors for asthma. Respirology 9:493-498.

Warner JO, Naspitz CK and Cropp GJA (1998) Third international pediatric consensus statement on the management of childhood asthma. Pediatr Pulmonol 25:1-17.

\section{Internet Resources}

GINA Report, Global Strategy for Asthma Management and Prevention, 2009. http://www.ginasthma.org/Guidelineitem.asp??11=2\&12=1 \&intId=1561 (June, 2009).

\section{Associate Editor: Francisco Mauro Salzano}

License information: This is an open-access article distributed under the terms of the Creative Commons Attribution License, which permits unrestricted use, distribution, and reproduction in any medium, provided the original work is properly cited. 